\title{
Edible Oil and Fat Consumption Patterns Among Turkish Consumers-A Case Study of Manisa city
}

\author{
Zeynep Aksoylu Özbek, Kıvılcım Çelik, Pelin Günç Ergönül**
}

Manisa Celal Bayar University, Faculty of Engineering, Department of Food Engineering, Yunusemre, Manisa, Turkey

\section{ISSN: 2640-9208}

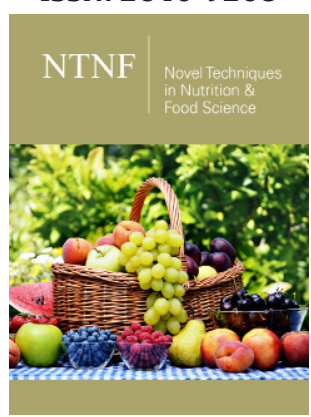

*Corresponding author: Pelin Günç Ergönül, Department of Food Engineering, Turkey

Submission: 侮June 24, 2020

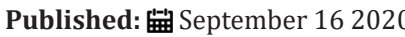

Volume 5 - Issue 1

How to cite this article: Zeynep Aksoylu Özbek, Kıvllcım Çelik, Pelin Günç Ergönül. Edible Oil and Fat Consumption Patterns Among Turkish Consumers-A Case Study of Manisa city. Nov Tech Nutri Food Sci. 5(1). NTNF. 000605. 2020.

DOI: 10.31031/NTNF.2020.05.000605

Copyright@ Pelin Günç Ergönül. This article is distributed under the terms of the Creative Commons Attribution 4.0 International License, which permits unrestricted use and redistribution provided that the original author and source are credited.

\begin{abstract}
The aim of this study is to identify the edible oils and fat consumption habits of Turkish consumers. A questionnaire to evaluate the attitude of consumers toward various edible oils and fats was administered to 300 individuals in Manisa central districts. Olive and sunflower oils were reported to be consumed daily, while hazelnut and corn oils were not preferred. "Brand" (35\%) was the primary influencer of edible oil purchasing decision of Turkish consumers. On the other hand, the most important criterion in the oil consumption of the respondents was "flavor" (41\%). The present study also showed that Turkish consumers have positive attitudes towards olive oil and other vegetable oils.
\end{abstract}

Keywords: Consumer; Consumption; Turkey; Fat; Manisa; Oil; Questionnaire

\section{Introduction}

Proteins, carbohydrates and fats play important roles in a balanced diet. Among these three essential nutrients, the highest energy is provided by fats. Today, especially in developed countries, consumers willing to pay attention to their health also change their eating habits. In this context, edible OİL and fat choices have been influenced by healthy diet trend. However, this change highly depends on cultural habits of consumers.

Fats and oils are among our indispensable food sources in terms of their ability to carry fatsoluble vitamins. Moreover, they contain some essential molecules that cannot be synthesized in the human body [1,2]. Fats have great importance in human nutrition as an energy source. As a comparison, 9.3 calorie are produced as a result of 1 gram of fat, whereas 1 gram of protein gives 4 calories, and 1 gram of carbohydrate give 4.5 calories to human body [2-4].

In addition to meeting the energy needs, fats contribute to many physiological and biological functions in the body [5]. Fat-soluble vitamins are responsible for many biological functions in the body as well as they act as structural material of all cells and organs [2]. Fats and oils are essential components of foods. It creates the desired texture and flavor in addition to the fullness of the products [6,7]. Additionally, they create the feeling of satiety in humans [8]. They serve as insulators in maintaining body temperature [6]. Oils are located among the protein layers in cell membrane and act as filter for the substances to be taken by a cell [8]. Furthermore, they and/or their products are used for non-food applications [2,4]. They are essential to transfer heat in food processes [2].

In a regular diet, $25-30 \%$ of the total daily energy requirement should be provided by fats $[4,9]$. However, energy obtained from oils should not exceed $35 \%$ of the total energy, while it should not be less than $20 \%$. Excess fat is stored in the human body and might cause cardiovascular diseases. Another issue to be considered in daily oil consumption is the saturation degree of the oil. The American Heart Association [10] recommends that $1 / 3$ of your daily need be made from saturated (i.e. butter, margarine), $1 / 3$ of unsaturated (i.e. olive oil), $1 / 3$ of polyunsaturated (i.e. sunflower, corn, soybean oil) fatty acids.

A person who weighs an average of $70 \mathrm{~kg}$ needs at least $1700 \mathrm{kcal}$ every day. When it is accepted that $35 \%$ of the daily energy need, which is $1700 \mathrm{kcal}$ according to healthy nutrition conditions, $595 \mathrm{kcal}$ should be provided by oils and fats [4]. According to regular nutrition 
rules, liquid foods contribute to $1 / 3$ of the daily fat intake, while solid fat consumed at breakfast contribute to $1 / 3$, and other foods including cheese, milk, and nuts contribute to $1 / 3$ of the daily fat intake [3]. An adult need to consume $24 \mathrm{~kg}$ of fat per year for balanced nutrition [11]. According to 2016 data, including olive oil, in Turkey 966 thousand tons of vegetable oil are produced. The amount of vegetable oil per person was determined as $21.9 \mathrm{~kg}$ $[3,12]$. However, per capita vegetable oil consumption is $19 \mathrm{~kg}$ in Turkey [11]. On the other hand, vegetable oil consumption per person is $15 \mathrm{~kg}$ in India, $26 \mathrm{~kg}$ in China, $57 \mathrm{~kg}$ in the USA and $60 \mathrm{~kg}$ in EU countries [3]. Compared to developed countries, per capita consumption of vegetable oil in Turkey seems to be lower.

Fats used in human nutrition are classified in various ways. Edible oils are divided into two main classes, animal and vegetable oils. Of these, oils of animal origin, fats obtained from bovine and ovine animals and their milk and various fish. Vegetable oils are obtained from seeds and fruits of plants. Vegetable oils are divided into two groups as fats and oils. Solid vegetable oils are generally grown in tropical regions and are obtained from the fruits of cocoa, coconut and palm plants. These vegetable oils are solid at room temperature and rich in saturated fatty acids. Fats produced by hydrogenation of vegetable oils and margarines containing water or milk in emulsion are also included in this group [4,13]. On the other hand, liquid vegetable oils are mostly obtained from seeds such as sunflower, soybean, canola and cotton, and $97-99 \%$ of the compositions of these vegetable oils consist of triglycerides [14].

Products rich in olive oil in the Mediterranean region, rapeseed in Europe, sesame oil in India and soybean oil in China have been extensively used. Today, $80 \%$ of the world's edible oils and fat production is made from vegetable oils, and soybean oil is the most widely used oil [6]. In Turkey, sunflower, corn, peanut, soybean, cotton, canola and palm oil as well as butter, margarine and olive oil are frequently consumed $[4,5,11]$.

So far, many studies have been conducted on the determination of the consumption habits of edible vegetable oil, olive oil and animal fats, and their effects on health and purchasing attitudes [11,15-36]. However, no study has been carried out to determine consumption patterns of edible oils and fats among individuals living in Manisa. Therefore, it was aimed

(a) to reveal the edible oil and fat buying behaviors of consumers with different income groups living in Manisa province, (b) to determine the main factors that dominate the edible oil preferences.

\section{Material and Method}

In this study, the questionnaire was applied to randomly selected 300 volunteer individuals, 150 of whom were women and 150 men, in the central districts of Manisa in 2014. Manisa is the one of the major cities of Aegean Region and Turkey with its booming economy and growing population. Manisa has two central districts, namely Şehzadeler and Yunusemre. Their populations were 166,443 and 204,436, respectively in 2014 [37]. The size of sample was estimated using population proportion through simple random sampling as follows:

$$
\left.n=((N \times P(1-P))) /\left([(N-1)] \wedge\left(\sigma_{-} P \wedge 2+P(1-P)\right)\right)\right)
$$

Here,

$\mathrm{N}=$ the actual size of the target population (total of 370.879)

$\mathrm{P}=$ estimated proportion of the population $(0.5)$

$\sigma \mathrm{p}=$ desired varience of the population (confidence interval of the $95 \%$ and error margin of $0.075,1.96 \sigma p=0.0075, \sigma p=$ 0.038265) (Newbold et al., 2013)

A sample of 171 observations is needed. However, the questionnaire was administered to 300 participants to ensure the reliability of the study. The questionnaire was conducted using face-to-face interview technique. The questionnaire was divided into two parts. In the first part, 6 questions about demographic characteristics and the second part 18 questions about fat and oil consumption habits were asked to the consumers. The questionnaire took approximately 15 minutes to complete. Data were evaluated using simple statistical methods in Excel.

\section{Results and Discussion}

\section{Sociodemographic characteristics of the participants}

The sociodemographic characteristics of 300 people living in Manisa city center are given in Table 1. Individuals from different age groups, education levels, income levels and occupational status were included in the survey. The number of male and female participants were chosen equally (50\% female and 50\% male). Age distribution ratios of the participants were very similar. It was found that $57 \%$ of the respondents were married and $51 \%$ of them were the consumers who have university and college education.

Table 1: Separated in two pages. Please combine in one page

\begin{tabular}{|c|c|c|}
\hline Characteristic & $\mathbf{n}$ & \\
\hline Gender & 150 & 50 \\
\hline Female & 50 & 150 \\
\hline Male & & 102 \\
\hline Age (Years) & 99 & 34 \\
\hline $18-30$ & 99 & 33 \\
\hline
\end{tabular}




\begin{tabular}{|c|c|c|}
\hline Education & & \\
\hline Elementary School & 63 & 21 \\
\hline High School & 66 & 22 \\
\hline Undergraduate & 153 & 51 \\
\hline Graduate & 18 & 6 \\
\hline \multicolumn{3}{|l|}{ Marital Status } \\
\hline Single & 99 & 33 \\
\hline Married & 171 & 57 \\
\hline Divorced or widowed & 30 & 10 \\
\hline \multicolumn{3}{|l|}{ Occupation } \\
\hline Full-time labourer and employee & 111 & 37 \\
\hline Student & 108 & 36 \\
\hline Unemployed & 36 & 12 \\
\hline Retiree & 21 & 7 \\
\hline Housewife & 21 & 7 \\
\hline Part-time labourer & 3 & 1 \\
\hline \multicolumn{3}{|l|}{ Monthly household income (Turkish Lira) } \\
\hline$<500$ & 3 & 1 \\
\hline $500-1000$ & 48 & 16 \\
\hline $1000-1500$ & 21 & 7 \\
\hline $1500-2000$ & 48 & 16 \\
\hline $2000-2500$ & 51 & 17 \\
\hline $2500-3000$ & 45 & 15 \\
\hline$>3000$ & 84 & 28 \\
\hline
\end{tabular}

\section{Consumption patterns of edible oils and fats among Turkish consumers}

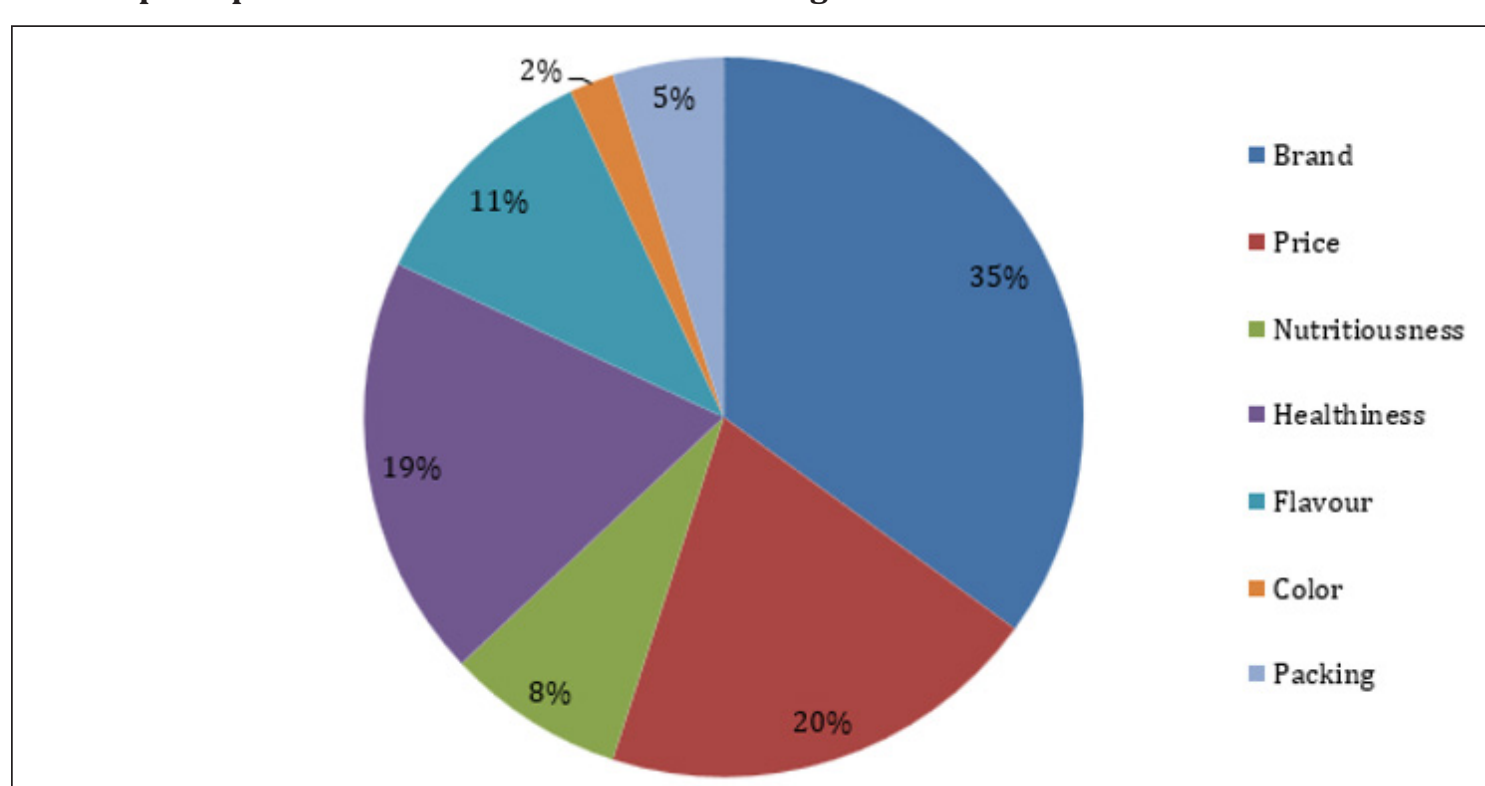

Figure 1: Most important criteria for edible oils and fats purchasing decisions of the participants.

Important criteria which influenced the edible oil or fat purchasing decision of consumers are illustrated in Figure 1. "Brand" was the most significant factor for Turkish consumers (35\%, $n=105)$. Similar results were previously reported for different cities of Turkey. According to the findings of a survey carried out in Samsun city (in Black Sea region), health was reported as the most important factor in oil consumption for the participants and followed by brand and taste [11]. Another study revealed that the most important reason for the oil preference of the individuals living in Ordu city (in Black Sea region) was health [33]. On the 
other hand, the participants from Dikili district of Izmir reported that the least important criterion in oil consumption was packaging [15]. Similarly, as a result of a study performed in Dehradun city, consumers reported that the critical criterion in oil consumption was brand [28]. In a survey dealing with edible oil consumption habits and perception of Ghana individuals, consumers selected the type of meal as the most influential decision driver for unrefined oil and nutritional value for refined oil [24]. Contrary to our results, survey studies carried out in Spain, USA, Italy and Northern California showed that price was the most important factor affecting the olive oil purchasing decision of the consumers [18,21,31,32]. The most surprising output of this question in our survey is oil prices $(20 \%$, $\mathrm{n}=60$ ) which was considered more important than nutritiousness $(8 \%, n=24)$ by the consumers living in Manisa.

Table 2 summarized the frequent use of surveyed oils and fats in soups and vegetables (Question 1), fries (Question 2), pastry \& pastries (Question 3) and salads (Question 4). As can be seen in Table 2, sunflower and olive oils were the most commonly used oils in vegetables and soups, while sunflower and corn oils were generally used for frying. Besides, margarine and butter were mostly chosen for pastry and pastry products, whereas Turkish consumers preferred to use sunflower and olive oils in salads. Our results are in accordance with the findings of [19], who reported that olive oil was generally used for cooking $(59 \%, n=236)$ and salads $(39 \%$, $\mathrm{n}=156$ ) in Gölbaşı district of Ankara (capital of Turkey). In another study conducted with 650 female participants in Gölbaşı district of Ankara, margarine (83.70\%, $\mathrm{n}=544)$, sunflower oil $(80.30 \%, \mathrm{n}=522)$ and butter (58\%, $\mathrm{n}=377$ ) were found to be used mainly for cooking [38]. Consumers living in another Aegean region city, namely Aydın, stated that olive oil was consumed in hot meals $(60.75 \%, n=113)$, breakfast (17.74\%, $\mathrm{n}=33$ ) and salads (4.84\%, $\mathrm{n}=9$ ) [34].

Table 2: Frequency and purposes of using edible oils and fats.

\begin{tabular}{|c|c|c|c|c|}
\hline \multirow{2}{*}{$\begin{array}{c}\text { Type of } \\
\text { Edible Oils } \\
\text { and Fats }\end{array}$} & \multicolumn{4}{|c|}{ Number of Participants (n) } \\
\cline { 2 - 5 } & $\mathbf{Q 1}$ & $\mathbf{Q 2}$ & $\mathbf{Q 3}$ & $\mathbf{Q 4}$ \\
\hline Margarine & 127 & 8 & 228 & 1 \\
\hline Butter & 55 & 13 & 136 & 4 \\
\hline $\begin{array}{c}\text { Sunflower } \\
\text { oil }\end{array}$ & 196 & 174 & 84 & 194 \\
\hline Olive oil & 201 & 52 & 30 & 256 \\
\hline Corn oil & 41 & 125 & 14 & 65 \\
\hline Tail oil & 0 & 0 & 0 & 0 \\
\hline Fish oil & 0 & 0 & 0 & 0 \\
\hline Soybean oil & 0 & 0 & 0 & 2 \\
\hline Hazelnut oil & 2 & 2 & 4 & 0 \\
\hline
\end{tabular}

In a study conducted in Samsun, sunflower oil was reported to be consumed in meals $(89.19 \%, n=535)$, while olive oil in salads
(84.62\%, n=508) [11]. A recent study carried out in Muğla city (in Aegean region) revealed that olive oil was usually used in salads (95.40\%, $n=397$ ) and cold vegetable dishes (92.50\%, $n=385$ ) [29]. On the other hand, consumers living in Tekirdağ (Thrace Region) used olive oil as cooking $(44.86 \%, \mathrm{n}=83$ ) and salad oil $(43.8 \%$, $\mathrm{n}=81$ ) [35]. As can be understood from the findings of similar studies explained above, edible oil preferences are generally different in various regions of Turkey due to cultural differences. Due to the abundance of olive oil production in Aegean region of Turkey, the respondents living in different cities of this region prefer to consume olive oil commonly in their diet. Similarly, to studies in Turkey, a survey study carried out in the USA showed that olive oil was usually used for cooking [32]. In a survey dealing with edible oil consumption and preference of Ghana individuals, participants reported that both refine, and unrefined oils were used for cooking, frying, grill and in soups [24]. It is clear that the consumers' perceptions of oil selection can be influenced by their habits and cultures.

Edible oil and fat storage preferences of consumers are given in Table 3. More than half of the respondents $(57 \%, \mathrm{n}=171)$ stated that they stored oil in a dark and cool place, while some $(38 \%, n=114)$ reported that they left it at room temperature in their kitchens. The majority of the respondents $(96 \%, n=288)$ reported that they kept their fat in refrigerator conditions. Fats like margarine and butter should be stored under refrigerator conditions. Oils should be stored in dark and cool places, as pro-oxidants such as temperature, light and oxygen accelerate the oil oxidation reactions [2,39]. The findings of the present study showed that most of the participants living in Manisa kept the edible oils and fat under proper storage conditions.

Table 3: Storage conditions of edible oils and fats.

\begin{tabular}{|c|c|c|}
\hline Storage Conditions & Edible Oil & Edible Fat \\
\hline Refrigerator & $5 \%$ & $96 \%$ \\
\hline Dark and cool place & $57 \%$ & $2 \%$ \\
\hline $\begin{array}{c}\text { In the kitchen at room } \\
\text { temperature }\end{array}$ & $38 \%$ & $2 \%$ \\
\hline
\end{tabular}

Reusing or reheating of frying oils is an ordinary method but is not advisable in terms of health effects. As can be seen in Figure 2, most of the participants $(57 \%, n=171)$ agreed with the statement "I change the frying oil after every use". However, some of the participants $(21 \%, n=36)$ reused the frying oil until it becomes darker. In summary, these findings indicate that Turkish consumers are aware of the health risks related with the reusing of frying oils multiple times. Therefore, they replace the oil very often for frying purposes. The most important criterion for oil consumption of Turkish consumers was flavor $(41 \%, \mathrm{n}=123)$. This was followed by cooking (37\%, $n=111)$, health $(14 \%, n=42)$ and habit $(8 \%, n=24)$. Our results are not in accordance with the findings of $[11,33]$, who reported being healthful as the most significant determinant for edible oil and fat consumption for Turkish consumers living in Samsun and Ordu cities, respectively. 


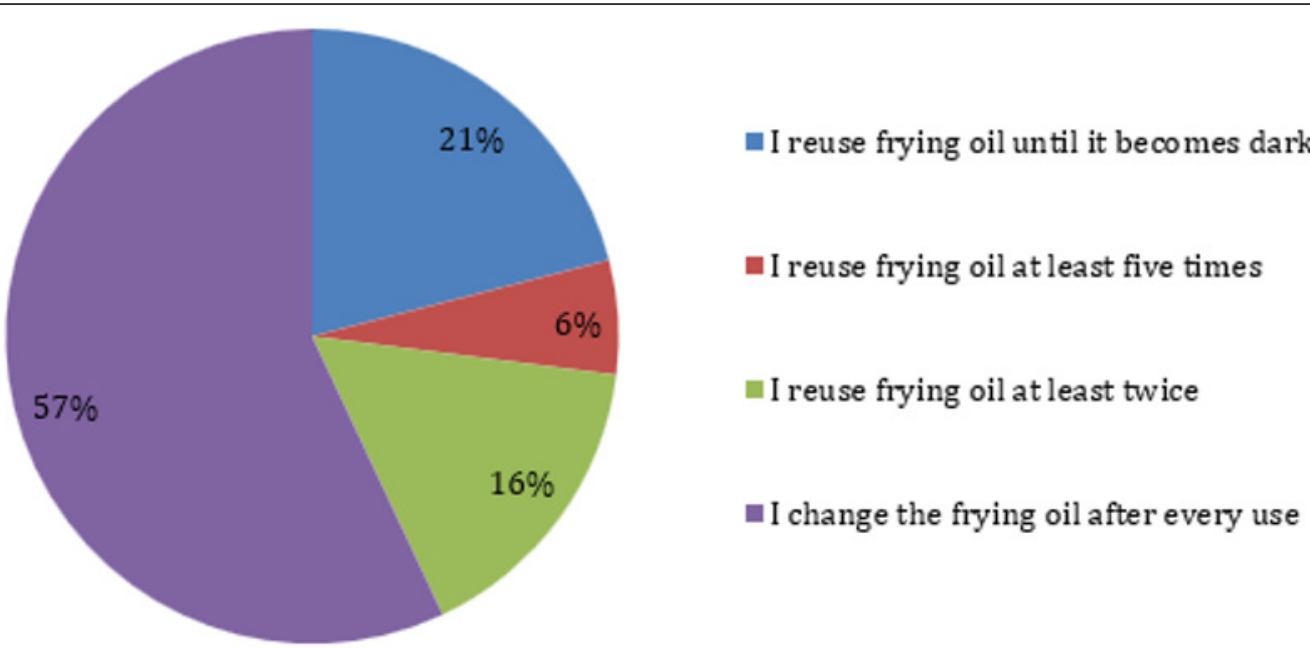

Figure 2: Reusing frequency of frying oils.

In the present study, we examined when butter and olive oil were mainly consumed. Participants reported that they consumed butter mostly at breakfast $(66 \%, \mathrm{n}=198)$, and olive oil mostly for cooking $(91 \%, n=273)$. Our results are in accordance with the findings of [19], who stated that olive oil was generally used in cooking (59\%, $n=236)$ in Gölbaşı district of Ankara. Similarly, consumers living in cities of Aydın (60.75\%, n=113) and Tekirdağ (44.86\%, n=83) preferred to use the olive oil for cooking, while it was generally used as salad oil by consumers in Muğla city (95.4\%, $n=397)[29,34,35]$. Contrary to our results, according to the results of another study conducted in Gölbaşı district of Ankara, butter $(58 \%, n=377)$ was generally used for cooking [38]. In conclusion, surveys conducted in Turkey show that olive oil is frequently used as salad oil and for cooking, whereas butter is generally consumed in breakfast and used for cooking (Table 4).

Table 4: Consumption of olive oil and butter.

\begin{tabular}{|c|c|c|}
\hline Time of Consumption & Butter & Olive Oil \\
\hline Breakfast & $66 \%$ & $9 \%$ \\
\hline Meal & $34 \%$ & $91 \%$ \\
\hline
\end{tabular}

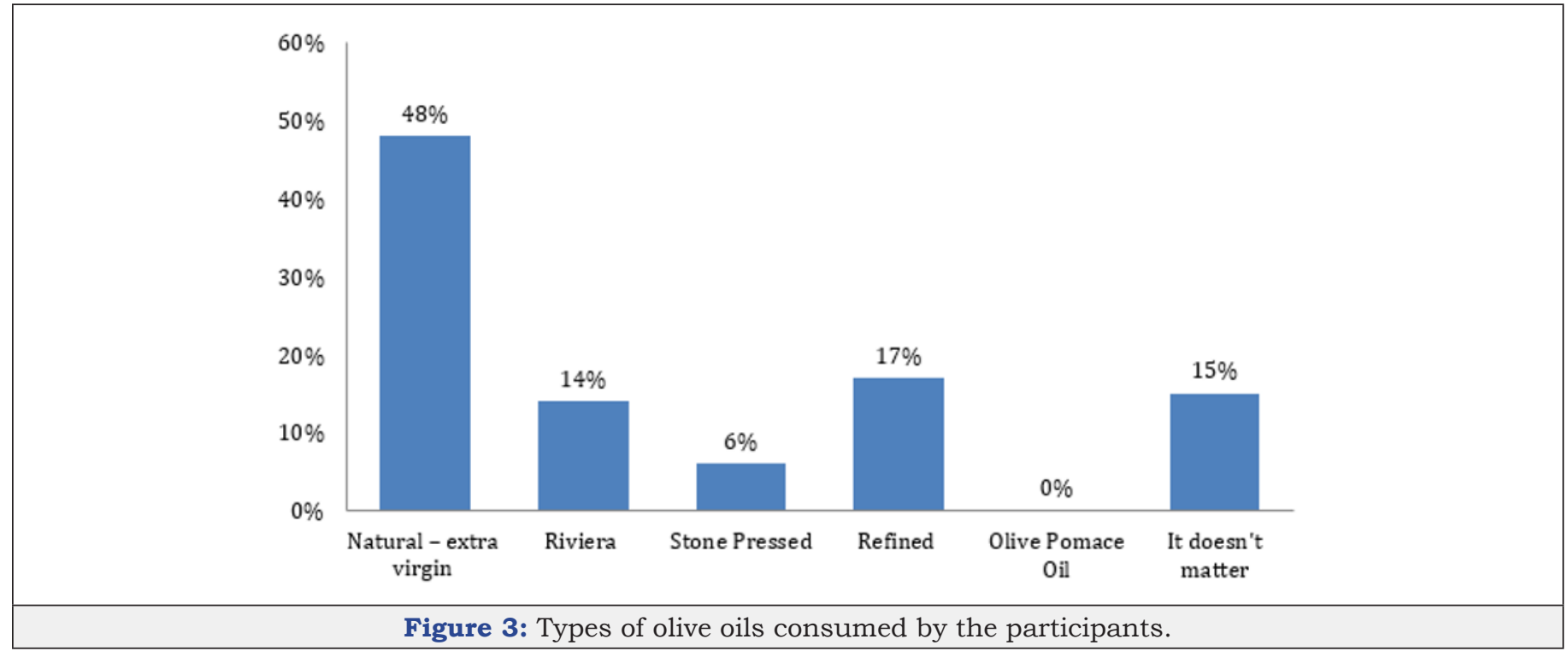

Olive oil production and consumption in the Aegean region of Turkey is very common. Most of the consumers surveyed reported that they preferred natural virgin olive oil (48\%, $n=144)$. In addition, some of the participants $(15 \%, n=45)$ reported that type of olive oil was not a key determinant for consumption. The quality, flavor, smell and aroma of olive oil were not considered as essential influencers by these consumers. Our findings agreed with the results of $[15,34]$, who reported that extra virgin olive oil was the most consumed type of olive oil by consumers living in Dikili district of Izmir city as well as consumers in Aydın city. However, unlike consumers from Aegean region, individuals living in Ankara, the capital found in central Anatolia of Turkey, reported that they mostly preferred riviera olive oil [19]. Considering the findings of all these studies, there are differences in olive oil type consumed between consumers living in various regions of Turkey. Similarly, to our results, Spanish and Northern California consumers reported 
that extra virgin olive was most preferred olive oil type $[18,21]$. Extra virgin olive oil is an essential quality parameter in olive oil for consumers around the world (Figure 3).

In our study, the place of purchase of the edible oils and fats was investigated. Turkish consumers living in Manisa city reported that they bought butter from dairy $(64 \%, n=192)$, markets $(25 \%, n=75)$ or directly from producers (unbranded) (11\%, n=33). Additionally, bowl package $(54 \%, \mathrm{n}=162)$ was the most preferred package for margarines. Also, participants stated that they preferred brick margarine $(23 \%, n=69)$, olive oil added margarine $(18 \%, n=54)$, liquid margarine $(4 \%, n=12)$ and tin-packed margarine $(1 \%, n=3)$. Similar results were previously reported for different cities of Turkey. According to the findings of a survey carried out in Samsun, consumers reported that they generally bought vegetable oils from market (86\%, $n=516$ ) [11]. Other study of $[15,34,35]$, who reported that the participants usually bought olive oil from market in Dikili (30\%, n=37), Aydın (32,26\%, n=60) and Tekirdag (69.2\%, n=128) cities, respectively. Consumers living in Ordu city, stated that the participants frequently bought hazelnut oil from market $(89.99 \%$, $\mathrm{n}=245$ ) [33]. Similar to our results and another studies, Ghanaian consumers purchased the unrefined oils from open markets and refined oils from supermarket [24]. Another study in Dehradun city reported that participants bought oils from a local store [28]. Consumers in the US and Northern California indicated that they bought oils from supermarkets or special (gurme) stores [21,32].

Comparison of edible oil types in terms of price affordability can be seen in Figure 4. Participants reported that butter (95.33\%, $\mathrm{n}=286)$ was the most affordable, followed by olive oil ( $94 \%, \mathrm{n}=282)$, corn oil (96.33\%, $\mathrm{n}=289)$, and sunflower oil (92.33\%, $\mathrm{n}=277)$. Olive oil was considered as more expensive than butter $(90.66 \%, \mathrm{n}=272)$, sunflower oil (92.33\%, $n=277)$, and corn oil ( $89 \%, n=267)$. On the other hand, consumers stated that butter was more expensive than sunflower oil $(71 \%, \mathrm{n}=213)$, and corn oil $(70.33 \%, \mathrm{n}=211)$, except olive oil. They also stated that corn oil was more expensive than sunflower oil $(61.66 \%, \mathrm{n}=185)$. Our study showed that margarine was the cheapest edible oil, while olive oil was the most expensive edible oil in Manisa city.

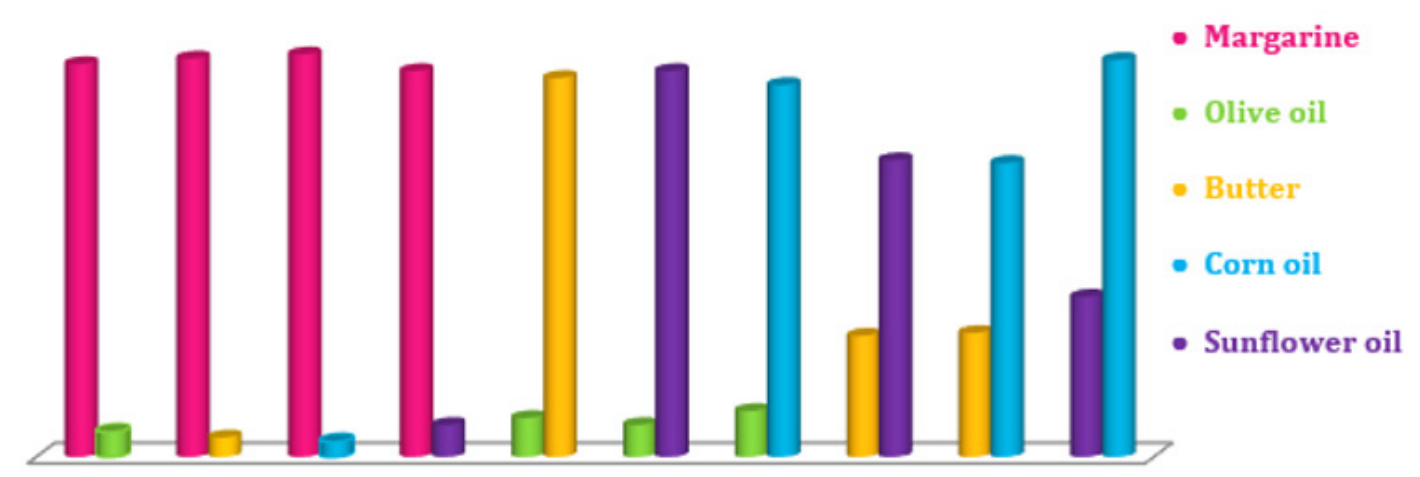

Figure 4: Comparison of edible oils and fats in terms of price compatibility.

The comparison of edible oils and fats in terms of taste is illustrated in Figure 5. Olive oil was more delicious than margarine (91.66\%, $\mathrm{n}=275)$, butter $(52.33 \%, \mathrm{n}=157)$, sunflower oil $(68 \%$, $\mathrm{n}=204)$, and corn oil $(70 \%, \mathrm{n}=210)$. Participants stated that butter was more delicious than margarine (95.66\%, $\mathrm{n}=287$ ), sunflower oil (92.66\%, $n=278)$, and corn oil $(76.66 \%, n=230)$, except olive oil. In conclusion, olive oil was perceived as the most delicious oil by consumers living in Manisa.

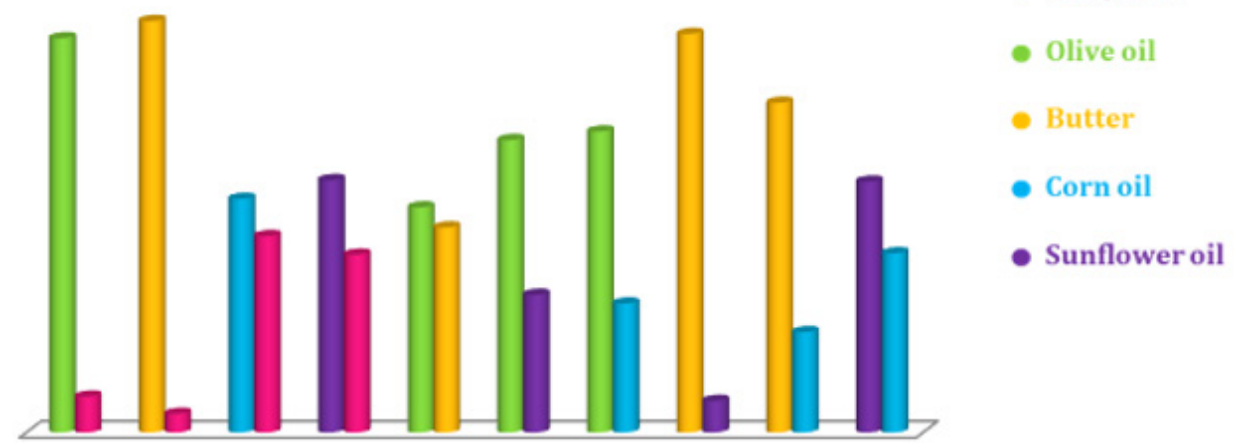

Figure 5: Comparison of edible oils and fats in terms of taste.

Ranking of importance of edible oils' properties are shown nutritiousness (52\%, $n=156)$, naturalness (73.66, $n=221)$, in Figure 6. Our results showed that taste $(68.33 \%, \mathrm{n}=205)$, boutique production $(26 \%, 33, \mathrm{n}=79), \mathrm{purity}(37 \%, \mathrm{n}=111)$, 
appearance $(41.66 \%, \mathrm{n}=125)$, having an ISO certification $(46.66 \%$, $\mathrm{n}=140)$, price $(44.66 \%, \mathrm{n}=134)$, brand $(47.33 \%, \mathrm{n}=142)$, being organic (35\%, $n=105)$, texture-consistency $(47.33 \%, n=142)$, and smell-aroma $(64 \%, 33, n=193)$ were the important criteria for consumers. Also, the participants stated that the saturation degree of edible oils was important $(35 \%, \mathrm{n}=105)$. Similarly, being organic was reported as an important characteristic for olive oil by Spanish consumers [18]. Furthermore, Italians considered the sensory characteristics as important influencers for olive oil [31]. In another study conducted in Ghana, participants revealed that the nutritional value and quality were important properties for refined oil. Also, consumers reported that price and nutritional value wee significant properties of unrefined oils [24]. Important properties in edible oils for consumers living in different regions may vary due to personal preferences and cultural differences.
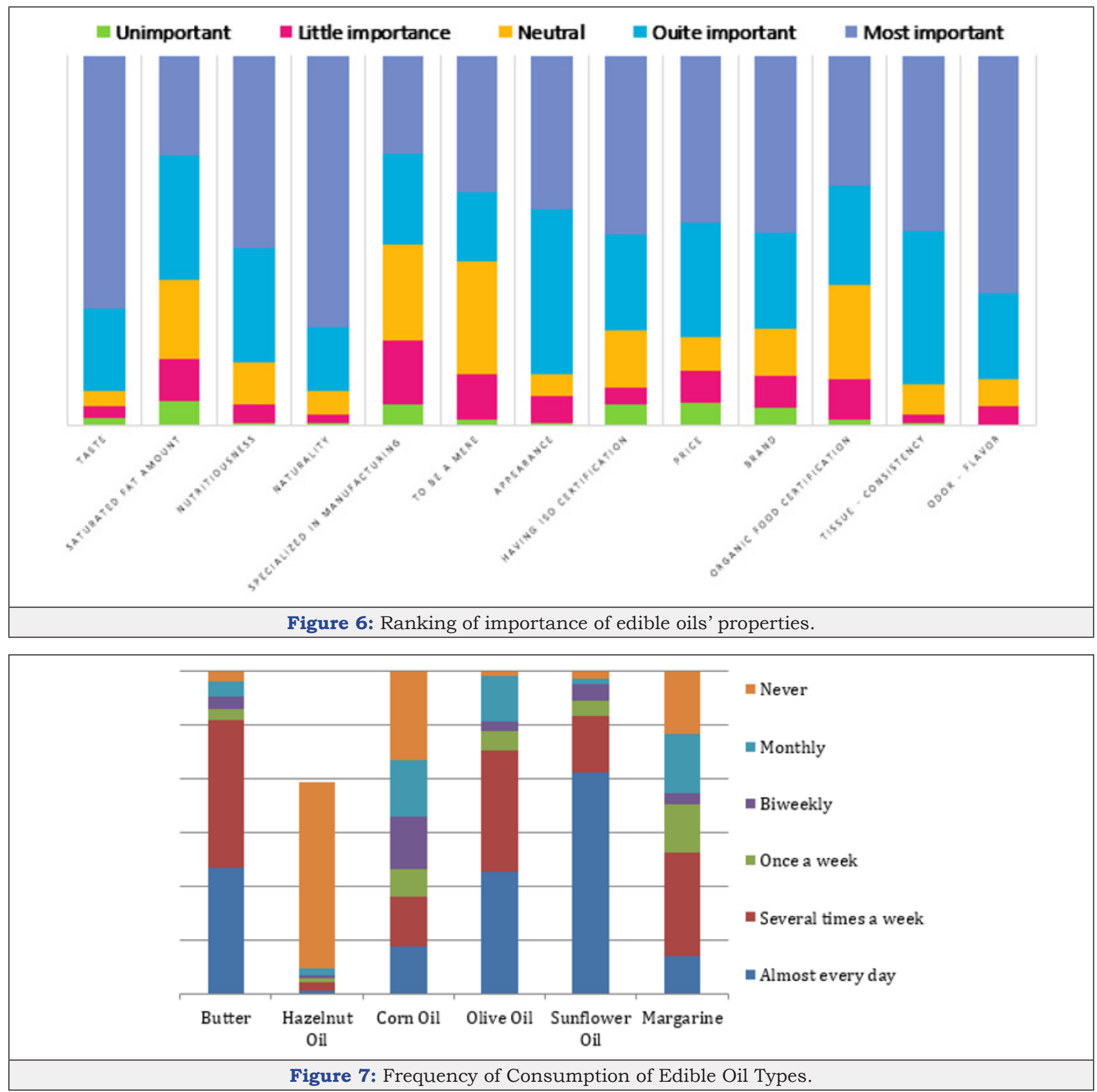

Figure 7 illustrates the frequency of edible oils and fats consumption by consumers living in Manisa. According to the findings of this survey, olive oil $(38 \%, n=114)$ and sunflower oil $(68.66 \%, n=206)$ were the most frequently oils in daily diet. Participants stated that butter $(45.66 \%, \mathrm{n}=137)$ was used several times a week and margarine was used once a month $(32 \%, n=96)$. 
Besides, hazelnut oil (57.66\%, n=173) and corn oil (27.66\%, n=83) were not generally used by the participants. Our findings agreed with the results of [36] who reported that sunflower oil $(48.9 \%$, $\mathrm{n}=173$ ) was the most consumed oil in Eskișehir city (in Central Anatolia Region). Similarly, as a result of a study, consumers stated that sunflower oil $(55 \%, n=242)$ and butter $(87 \%, n=383)$ were most frequently consumed edible oil and fat, respectively [26]. Our results are not in accordance with the findings of $[19,38]$, who reported that participants living in Gölbaşı district in Ankara did not consume olive oil $(40 \%, n=160)$, while margarine $(83.7 \%$, $\mathrm{n}=544$ ) was the most frequently consumed fat. On the other side, participants living in Ordu city generally consumed butter (71.32\%, n=194) and hazelnut oil (61.76\%, n=168) [33]. A study performed in Italy revealed that olive oil was the most consumed edible oil [31]. In the Mediterranean culture, olive oil dominates the daily diet. Studies summarized above showed that olive oil is frequently consumed in the Aegean region of Turkey, where the Mediterranean-type diet is adopted [40,41]. On the other hand, a survey study carried out in Ghana showed that palm oil, palm kernel oil, coconut oil and shea butter were the most consumed edible oils [24]. Findings of similar studies prove that different societies have different food intake patterns thanks to their cultural variations. In addition, [16] reported that economic income was a key determinant in consumption quantity of edible oils and fats.

This survey study has some limitations. Firstly, the sample size is not enough to generalize the results of this study to all Aegean region of Turkey. Secondly, the number of participants from each sociodemographic group should be balanced to reduce variability.

\section{Conclusion}

The criteria that dominate edible oil consumption of consumers living in Manisa city were determined. In conclusion, the majority of the participants consumed butter at breakfast $(66 \%, \mathrm{n}=198)$ and used olive oil for cooking ( $91 \%, n=273$ ). Half of the participants preferred to consume extra natural virgin olive oil. Besides, margarine was considered as the cheapest and tasteless edible fat, whereas olive oil was the most expensive and delicious cooking oil. Furthermore, the majority of the consumers consumed olive oil and sunflower oil through their regular diet and never consumed hazelnut and corn oils. Regional differences as they reflect the habitual and cultural differences in Turkey cause differences in edible oil consumption habits. Further and detailed survey studies are needed to understand the roles of cultural differences in food consumption patterns.

\section{References}

1. Ergönül PG (2011) The effect of filter aids used in winterization on oil loss and quality of vegetable oil [Manisa Celal Bayar Üniversitesi].

2. Scrimgeour C (2005) Chemistry of Fatty Acids. In: Shahidi (Ed.), Bailey's Industrial Oil and Fat Products. (6 ${ }^{\text {th }}$ edn), pp. 1-39.

3. Arıoglu H (2016) Oil seeds and crude oil production in turkey, problems and solutions. Tarla Bitkileri Merkez Araștırma Enstitüsü Dergisi 25 357-368.

4. Onurlubaş HE, Kızılaslan H (2007) The future orientated expectations and developments in turkey vegetable oil industry.
5. Tarhan Ö (2008) The analysis of frequently consumed various cooking oil in turkey and fatty acid compositions of fatty seeds with gas chromatography. Karadeniz Technical University Institute of Natural Sciences.

6. Dunford NT (2004) Oil- and oilseed-based bioactive compounds and their health effects. In Nutritionally enhanced edible oil and oilseed processing, pp. 1-30.

7. Youssef MK, Barbut S (2011) Fat reduction in comminuted meat products-effects of beef fat, regular and pre-emulsified canola oil. Meat Science 87(4): 356-360.

8. Başoğlu F (2017) Yemeklik yağ teknolojisi. Dora Yayınları.

9. Gunstone FD (2009) Oils and fats in the food industry: Food industry briefing series. Nutritional properties, pp. 89-112.

10. https://www.heart.org/en/healthy-living/healthy-eating/eat-smart/ fats/saturated-fats

11.Gündüz O, Esengün K (2010) A Research on the vegetable oil consumption of households: a case of Samsun province. Karamanoğlu Mehmetbey University Journal of Social and Economic Research 12(19): 67-72.

12. Onat B, Arıoğlu H, Güllüoğlu L, Kurt C, Bakal H (2017) Dünya ve Türkiyede Yağlı Tohum ve Ham Yağ Üretimine Bir Bakıș. KSÜ Doğa Bilimleri Dergisi 20: $149-153$.

13. Harwood JL, Evans M, Ramji D, Murphy DJ, Dodds PF (2007) Medical and agricultural aspects of lipids. In: Gunstone, Harwood, Dijkstra (Eds.), ( $3^{\text {rd }}$ edn), The Lipid Handbook, pp. 703-756.

14. Griffith GR, Meilke KD (1979) Relationships among North American fats and oils prices. American Journal of Agricultural Economics 61(2): 335341.

15. Ağır M, Boran C, Özden F, Artukoğlu MM, Muhendisi Z (2018) A research on consumer preferences in olive oil: Case study for Dikili District of Izmir. Journal of Ege University Faculty of Agriculture 55(4): 81-90.

16. Akbay C (2007) Urban households' cooking oil and fat consumption patterns in Turkey: quality Vs. quantity. Quality and Quantity 41(6): 851-867.

17. Özbek, ZA, Çelik K, Ergönül PG (2020) Consumers Knowledge About Health Effects of Edible Oils and Fats in Turkey: A Questionnaire Study. Novel Techniques in Nutrition \& Food Science 4(4): 371-378.

18. Bernabéu R, Díaz M (2016) Preference for olive oil consumption in the Spanish local market. Spanish Journal of Agricultural Research 14(4): 11.

19. Cömert M, Adıyaman S, Özkaya FD (2012) Identifying local people’s knowledge level about olive oil: Example from golbasi, ankara. Olive Science 3(1): 1-9.

20. Daştan H, Aday MS, Yllmaz E (2009) Edible fats/oils consumption patterns of Turkish families. Akademik Gida 7(4): 6-13.

21. Delgado C, Rico AG, Guinard JX (2013) Evaluating bottles and labels versus tasting the oils blind: Effects of packaging and labeling on consumer preferences, purchase intentions and expectations for extra virgin olive oil. Food Research International 54(2): 2112-2121.

22. Diekman C, Malcolm K (2009) Consumer perception and insights on fats and fatty acids: Knowledge on the quality of diet fat. Ann Nutr Metab 54(Suppl 1): 25-32.

23. Eckel RH, Etherton PK, Lichtenstein AH, Rosett JW, Groom A, et al. (2009) Americans' awareness, knowledge, and behaviors regarding fats: 2006-2007. Journal of the American Dietetic Association 109(2): 288-296.

24. Nondzor HE (2015) Consumer knowledge, perception and preference of edible oil: evidence from Ghana. Science Journal of Business and Management 3(1): 17-23. 
25. Glanz K, Brug J, Assema P (1997) Are awareness of dietary fat intake and actual fat consumption associated?-A Dutch American comparison. European Journal of Clinical Nutrition 51(8): 542-547.

26. Göktaş B, Gül V (2018) Consumer's oil habits in turkey and thoughts on the brands that they purchase. In: Temizer, Baytal (Eds.), New Trends in Social Sciences-V, Turkey, p. 37.

27. Harel Z, Riggs S, Vaz R, White L, Menzies G (2001) Omega-3 polyunsaturated fatty acids in adolescents: knowledge and consumption. J Adolesc Health 28(1): 10-15.

28. Khanna A (2014) Consumer attitude and perception toward brands of edible oil: An Empirical Study 4(10): 8.

29. Küçükkömürler S, Uluksar FO (2018) Use of olive oil in Turkish cuisine culture, case of Muğla. Journal of Tourism and Gastronomy Studies 6(2): 194-212.

30. Lin CTJ, Yen ST (2010) Knowledge of dietary fats among us consumers Journal of the American Dietetic Association 110(4): 613-618.

31. Saba A, Natale R (1998) Attitudes, intention and habit: Their role in predicting actual consumption of fats and oils. Journal of Human Nutrition and Dietetics 11(1): 21-32.

32. Santosa M, Guinard JX (2011) Means-end chains analysis of extra virgin olive oil purchase and consumption behavior. Food Quality and Preference 22(3): 304-316.

33. Sayılı M, Gözener B, Kalpakoğlu G (2013) Hazelnut oil consumption of families in the central town of ordu province. Journal of Agricultural Faculty of Gaziosmanpasa University 30(1): 84-90.
34. Tunalıoğlu R, Cankurt M, Cobanoğlu F, Armağan G (2012) Consumer behaviors on olive oil. $10^{\text {th }}$ National Congress of Agricultural Economics, pp. 853-862.

35. Unakıtan G, Başaran B, Yılmaz F (2012) Analysis of preferences of olive oils consumption in Tekirdag province. $10^{\text {th }}$ National Congress of Agricultural Economics, pp. 956-963.

36. Yıldız Z, Yılmaz V, Kaşkır F, Baş M (2012) Using multivariate statistical methods segmentation of consumers according to their preferences of liquid oil packaging abstract. Dumlupınar University Journal of Social Sciences 1(32): 25-272.

37. https://tuik.gov.tr/Start.do

38. Yardımcı H, Özçelik AÖ (2006) Ankara İli Gölbașı İlçesinde Yetișkin Kadınların Beslenme Alışkanlıkları Ve Antropometrik Ölçümler. Beslenme Ve Diyet Dergisi.

39. Frankel EN (2005) Lipid oxidation. In: ( $2^{\text {nd }}$ edn), Woodhead Publishing Limited, UK.

40. Balcı YI, Ergin A, Karabulut A, Polat A, Doğan M, Küçüktașcı K (2014) Serum vitamin B12 and folate concentrations and the effect of the mediterranean diet on vulnerable populations. Pediatric Hematology and Oncology 31(1): 62-67.

41. Newbold P, Carlson WL, Thorne BM (2013) Statistics for business and economics: Pearson New Education Limited. In: Clave, Benson, Terry (Eds.), p. 1016. 